\title{
Spatial distribution of Crimean agroecological resources as a factor of variability of the main and secondary metabolites of grapes
}

\author{
Evgeniy Rybalko*, Elena Ostroukhova, and Svetlana Levchenko \\ All-Russian National Research Institute of Viticulture and Winemaking "Magarach" RAS \\ 31 Kirova Str., 298600 Yalta, Republic of Crimea, Russian Federation
}

\begin{abstract}
The work is aimed at identifying the relationship between agroecological conditions and the formation of carbohydrate-acid and phenolic grape complexes. The agro-climatic parameters of $14 \mathrm{cv}$. 'Cabernet Sauvignon' industrial vineyards located in five wine-growing regions of Crimea have been determined using the methods of geoinformation and mathematical modeling. According to the similarity of 9 agro-climatic characteristics, the vineyards are united into 6 clusters, significantly different from each other. The dispersion of the main and secondary metabolites of grapes, as well as technological indicators based on them in the harvest from the selected clusters, has been established. According to the combined mass concentration of anthocyanins in berries, potential amount of extractable anthocyanins, anthocyanin extractability, monophenolmonooxygenase activity, glucoacidimetric index and grape ripeness index the selected vineyard clusters are discriminated with Wilks L. $=0.09$ at $\alpha<0.00001$. Sugar content, active acidity index, glucoacidimetric index, and grape ripeness index were found to correlate inversely with the amount of precipitation during the growing season; anthocyanin extractability correlates directly with the Huglin and Winkler indices; monophenolmonooxygenase activity with the sum of active temperatures above $10{ }^{\circ} \mathrm{C}$, Huglin index, total precipitation per year and growing season.
\end{abstract}

\section{Introduction}

The quality of grapes and wine is greatly influenced by the agro-ecological parameters of grape growing area [1-5]. To select the territory for vineyards, to select the varieties and to determine the direction of raw material use, it is important to understand the regularities of the influence of environmental conditions on the formation of qualitative characteristics of grapes. Modern science considers a wide range of climatic indices as factors in the metabolism of the grape plant. Among them: Winkler index, heliothermal Huglin index, sum of active temperatures, sum of biologically effective temperatures, Selyaninov hydrothermal coefficient, amount of precipitation per year, amount of precipitation per

\footnotetext{
*Corresponding author: rybalko_ye_a@mail.ru
} 
growing season, etc. [5-8]. The more precise these characteristics are determined for a particular territory, the more effective will be its amplification. For this purpose various methods of data collection and processing are used: remote sensing of the Earth, geoinformation and mathematical modeling of spatial variation of climatic indicators under the influence of orographic, hydrological and geographical parameters of analyzed territories [9-14]. The amount of sunlight, heat supply, water regime of grape cultivation and an adaptive feature of variety to environmental influences largely predetermine the synthesis of many enzyme systems, primary and secondary metabolites of grape plant. This concerns carbohydrate-acid, phenolic and aroma-forming complexes, oxidase and hydrolytic enzymes [15-18]. In the case of red grapes, due to planetary climate change, the identification of territories with climatic parameters, which provide an optimal balance of anthocyanin complex formation and sugar accumulation during berry ripening, acquires particular importance. Thus, a direct correlation $(r=0.88-0.95)$ between the agro-ecological parameters, and the content of malvidin monoglucosides and their derivatives in the berry anthocyanin complex was established; the reverse correlation is between the same agroecological parameters and the content of cyanidin, petunidin and their derivatives [19].

This work is devoted to the study of the similarities and differences in the agroclimatic conditions of cv. 'Cabernet Sauvignon' industrial vineyards on the territory of the Crimean Peninsula and the parameters of carbohydrate-acid and phenolic maturity of the crop.

\section{Materials and methods}

\subsection{Vineyards}

Cv. 'Cabernet Sauvignon' vineyards have the following location: two vineyards (No. 1 and No. 2) in village Livadia, No. 3 - near the city of Yalta, No. 4 - in village Lazurnoe on the South Coast of Crimea, No. 5 - near the city of Alushta in the Mountain-valley region; No. 6, 7, 8 and 9 - in villages Morskoye, Veseloe, Privetnoye and Solnechnaya Dolina in the Mountain-valley seaside region. The following vineyards are located in the Western foothill-seaside region: No. 10, 11, 12 and 13 - in villages Orlovka, Osipenko, Uglovoye, and Vilino; the vineyard No. 14 - village Plodovoye in the Foothill region. Figure 1 shows the differences of vineyards by morphometric parameters of relief: the absolute altitude above sea level, steepness and exposure of the slope, the relative excess over the talweg.

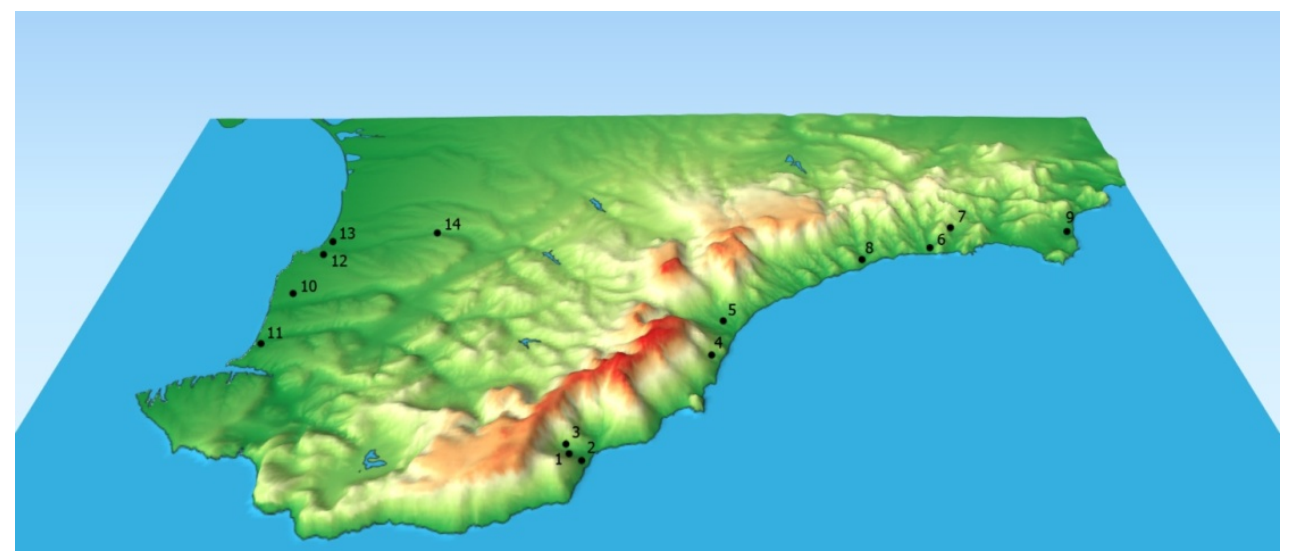

Fig. 1. Location of the analyzed vineyards of the Crimean peninsula. 


\subsection{Methods for determining the agroecological parameters of vineyards}

To assess the agro-ecological resources of vineyards the geographical coordinates of vineyards, their orographic and hydrological parameters were determined. Then, using data for 2015-2019 from stationary weather stations, geoinformation modeling method, digital terrain model SRTM-3, global climate model Worldclim ver. 2.0 and developed mathematical models, describing regularities of spatial variation of climatic indicators under the influence of orographic, hydrological and geographical factors [20-23], agroclimatic parameters were calculated in the location of each vineyard.

The sum of active temperatures above $10{ }^{\circ} \mathrm{C}\left(\sum \mathrm{t}^{\circ} \mathrm{C}_{10}\right)$, Huglin index $(\mathrm{HI})$, Winkler index (WI), average temperature of vegetation period ( $t_{\text {growing }}$ ), average temperature of September $\left(\mathrm{t}_{\text {Sept }}\right)$, annual precipitation $\left(\mathrm{P}_{\text {year }}\right)$, precipitation during vegetation period ( $\left.\mathrm{P}_{\text {growing }}\right)$, precipitation in September $\left(\mathrm{P}_{\text {Sept }}\right)$, Selyaninov hydrothermal coefficient (HTC) were determined for each vineyard.

\subsection{Sampling and methods of analysis}

Grape sampling was performed in the vineyards during the commercial harvest period. For the analysis of grapes, 500-600 $\mathrm{g}$ of berries of each sample were crushed in a blender (Moulinex-LM600E, France) for 2 minutes.

Technological evaluation of grapes was carried out according to the following parameters: mass concentration of sugars, titratable acids in terms of tartaric acid, active acidity $\mathrm{pH}$ [24]. Grape ripeness index $\left(\mathrm{RI}=\mathrm{Brix} \mathrm{pH}^{2}\right)$ and glucoacidometric index (GAI) were calculated. Monophenolmonooxygenase activity of must ( $\mathrm{A}_{\mathrm{MPhMO}}$ ) was determined by the oxidation rate of pyrocatechin solution. To determine the technological reserve of phenolic components (TRPh) must was heated and kept in the thermostat at $70{ }^{\circ} \mathrm{C}$ for 30 minutes with stirring. After cooling, the must was separated, and the concentration of phenolic compounds was measured using Folin-Chocalteu reagent [24]. The degree of transition of phenolic components into must was calculated during pressing of whole berries $\left(\mathrm{Ph}_{0} / \mathrm{TRPh}\right)$ and after 4 -hour infusion of the pulp $\left(\mathrm{Ph}_{4} / \mathrm{TRPh}\right)$.

The phenolic maturity of grapes was assessed by the Glories method, based on the determination of the mass concentration of anthocyanins in the grape berry $\left(\mathrm{ApH}_{1.0}\right)$, the potential amount of extractable anthocyanins $\left(\mathrm{ApH}_{3.2}\right)$, extractability of anthocyanins (Ea, or the fraction of anthocyanins extracted from the grape skin) [25].

\subsection{Statistical data processing}

The total number of grape samples was 58. All analyzes were carried out in 2-3 replicates. The experimental material was processed by methods of variance and discriminant analysis (using the Statistics 10 program). The statistical coefficients were verified for a significance level of $\alpha<0.05$. The informational value of the discriminant variables was estimated based on the Wilkes statistics.

\section{Results and discussion}

The results of determining climatic parameters of cv. 'Cabernet Sauvignon' vineyards by the methods of geoinformation and mathematical modeling and their statistical processing are presented in table 1 . The data in the table indicate that the geographical location of the vineyards caused the dispersion of their agroclimatic parameters at the level of significance $\alpha<0.005$ (for the Selyaninov hydrothermal coefficient $\alpha<0.03$ ). Nevertheless, according to the similarity of the 9 agroclimatic characteristics reflecting heat and moisture 
availability, the vineyards were combined (using cluster analysis) into 6 clusters, significantly differing from each other (Wilks L. $=0.0006 ;<0.00001$ ).

Table 1. Climatic parameters of the analyzed vineyards.

\begin{tabular}{|c|c|c|c|c|c|c|c|c|c|c|c|}
\hline$\stackrel{\Xi}{\tilde{N}}$ & 竞 & 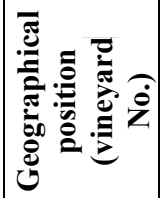 & 㟧 & 玨 & $\overline{3}$ & 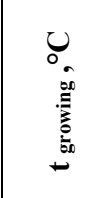 & 葛 & $\underset{\Xi}{U}$ & 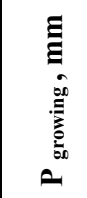 & 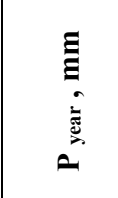 & 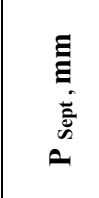 \\
\hline \multirow{9}{*}{ 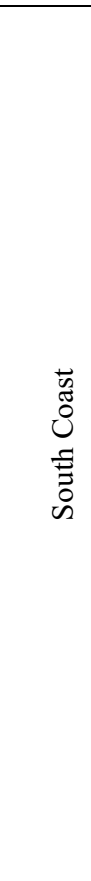 } & \multirow{4}{*}{ 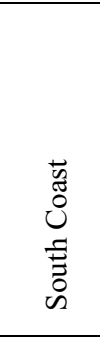 } & \begin{tabular}{|l} 
Livadia \\
$(1)$ \\
Mountain \\
\end{tabular} & 4360 & 2589 & 1921 & 20.9 & 20.3 & 1.04 & 210 & 798 & 53 \\
\hline & & $\begin{array}{l}\text { Livadia } \\
\text { (2) Sea }\end{array}$ & 4387 & 2846 & 2138 & 20.5 & 20.3 & 0.79 & 227 & 595 & 18 \\
\hline & & Yalta (3) & 4313 & 2895 & 2083 & 20.3 & 20.5 & 0.85 & 269 & 636 & 8 \\
\hline & & \begin{tabular}{|l} 
Lazurnoe \\
(4)
\end{tabular} & 4425 & 2719 & 1979 & 19.9 & 22.9 & 0.73 & 196 & 496 & 13 \\
\hline & 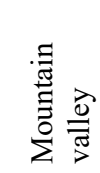 & $\begin{array}{l}\text { Alushta } \\
\text { (5) }\end{array}$ & 4307 & 2740 & 2038 & 20.4 & 21.9 & 0.73 & 219 & 512 & 12 \\
\hline & & $\begin{array}{l}\text { Morskoye } \\
(6)\end{array}$ & 4158 & 2855 & 2056 & 20.8 & 19.8 & 0.82 & 282 & 535 & 4 \\
\hline & $\frac{\vec{\partial}}{\bar{\sigma}}$ & \begin{tabular}{|l|} 
Veseloe \\
(7)
\end{tabular} & 4239 & 2702 & 1967 & 20.1 & 23.0 & 0.68 & 177 & 432 & 10 \\
\hline & $\stackrel{1}{\Xi}$ & \begin{tabular}{|l|} 
Privetnoye \\
$(8)$
\end{tabular} & 3567 & 2721 & 2139 & 20.9 & 20.2 & 1.08 & 115 & 368 & 16 \\
\hline & 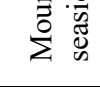 & \begin{tabular}{|l|} 
Sunny \\
Valley (9)
\end{tabular} & 4551 & 2731 & 2123 & 20.6 & 20.4 & 0.58 & 152 & 466 & 18 \\
\hline \multirow{5}{*}{ 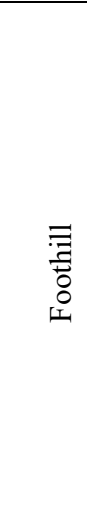 } & \multirow{4}{*}{ 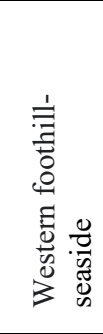 } & $\begin{array}{l}\text { Orlovka } \\
(10)\end{array}$ & 4307 & 2758 & 2039 & 20.5 & 20.4 & 0.53 & 255 & 463 & 75 \\
\hline & & \begin{tabular}{|l|} 
Osipenko \\
$(11)$
\end{tabular} & 4130 & 2557 & 1806 & 19.1 & 20.4 & 0.70 & 175 & 413 & 1 \\
\hline & & \begin{tabular}{|l|} 
Uglovoye \\
$(12)$
\end{tabular} & 3673 & 2646 & 1638 & 18.8 & 19.0 & 0.89 & 201 & 528 & 0 \\
\hline & & $\begin{array}{l}\text { Vilino } \\
(13)\end{array}$ & 3742 & 2634 & 1688 & 19.0 & 18.1 & 0.87 & 363 & 628 & 51 \\
\hline & 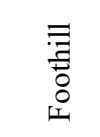 & $\begin{array}{l}\text { Plodovoye } \\
\text { (14) }\end{array}$ & 3884 & 2763 & 1728 & 19.4 & 17.2 & 0.57 & 188 & 502 & 6 \\
\hline \multicolumn{3}{|c|}{$\begin{array}{l}\text { Significance level (F- } \\
\text { criterion) of dispersion of the } \\
\text { indicator between vineyards, } \\
\alpha, \text { less than }\end{array}$} & 0.003 & 0.002 & 0.00001 & 0.0002 & 0.00001 & 0.03 & 0.005 & 0.00001 & 0.0002 \\
\hline
\end{tabular}


Cluster I included vineyards Alushta + Veseloye + Morskoye + Orlovka; cluster II Yalta + Livadia (2); cluster III - Livadia (1) + Lazurnoye + Sunny Valley; cluster IV Privetnoye; cluster V - Plodovoye + Osipenko; cluster VI - Vilino + Uglovoye.

Figure 2 visually illustrates the difference of vineyards clusters by agroclimatic parameters, the increase of values is marked by arrows on the axes of the diagram. At the same time, the discriminant function on abscissa axis explains the differences of vineyard clusters by $70 \%$, on ordinate axis - by $21 \%$. As can be seen from the diagram, the vineyards of clusters VI and V located in the Western foothill-seaside region of Crimea have the greatest moisture availability; the vineyard of the v. Privetnoe (cluster IV) has the lowest one. At the same time, the vineyard of village Privetnoe is characterized by high values of the Winkler index and Selyaninov's hydrothermal coefficient. The vineyards of cluster II located on the coast near Yalta and Livadia were characterized by the highest values of heat availability. It is noteworthy that vineyards located in different winegrowing regions of Crimea got into one cluster. Thus, cluster I included vineyards from the Mountain valley (Alushta), Mountain-valley seaside (v. Veseloe, Morskoye) and Western foothill-seaside (v. Orlovka) regions; cluster II included vineyards from the South Coast and Mountain-valley seaside regions.

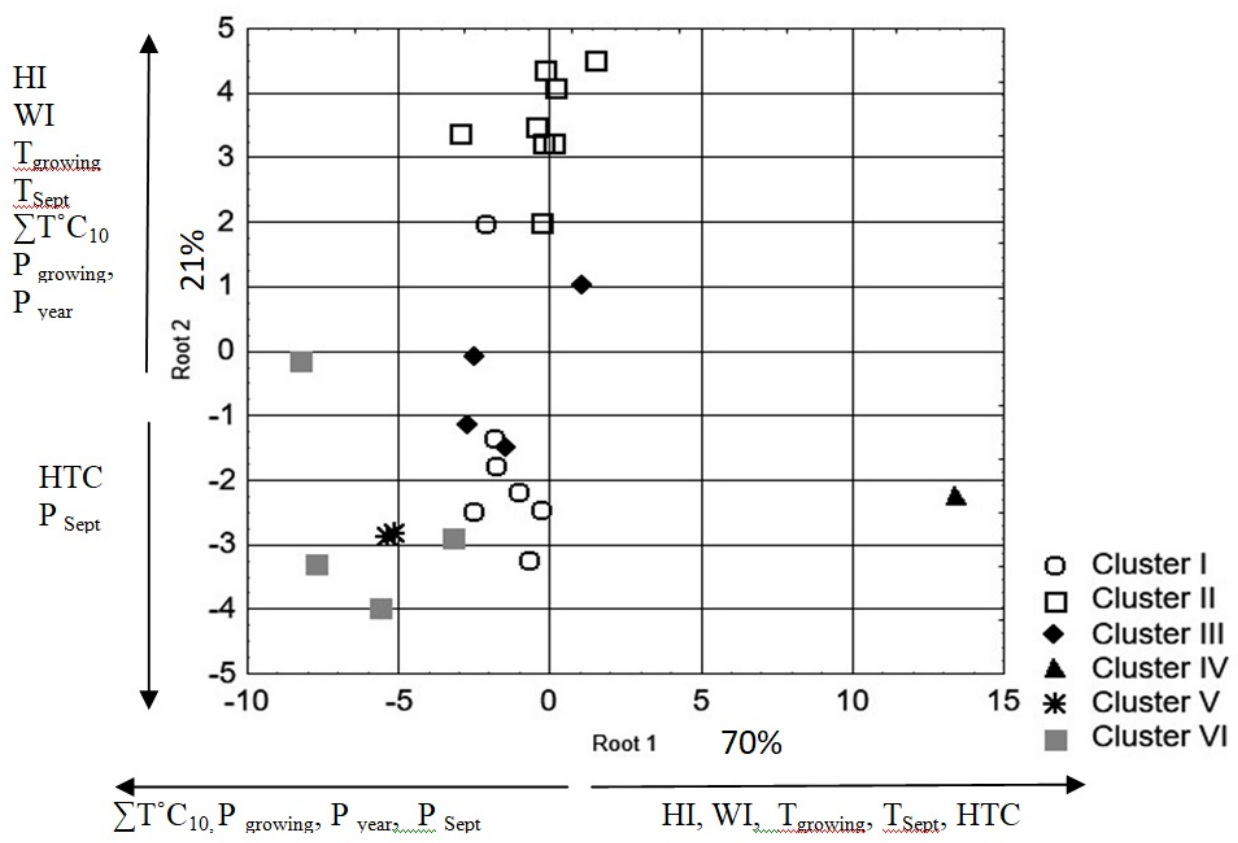

Fig. 2. Diagram reflecting the differences of selected clusters of vineyards by agroclimatic parameters: Cluster I - Alushta + Veseloye + Morskoye + Orlovka; cluster II - Yalta + Livadia (2); cluster III - Livadia (1) + Lazurnoye + Sunny Valley; cluster IV - Privetnoye; cluster V - Plodovoye + Osipenko; cluster VI - Vilino + Uglovoye.

Table 2 presents the values of some basic (content of sugars, titratable acids, active acidity and calculated indices on their basis) and secondary (phenolic components, oxidase activity) metabolites of 'Cabernet Sauvignon' yield, obtained in 2015-2019 in the vineyards of selected clusters. The content of sugars in berries during the industrial harvest of grapes ranged from $175 \mathrm{~g}$. L $\mathrm{L}^{-1}$ to $298 \mathrm{~g}$. L $\mathrm{L}^{-1}$ with an average value of $222 \pm 28 \mathrm{~g}^{-\mathrm{L}^{-1}}$, the value of active acidity - from 3.00 to 3.93. Statistical analysis of the data demonstrated a significant 
$(\alpha<0.008)$ dispersion of the sugar content index, active acidity, as well as the glucoacidometric index and the grape ripeness index by vineyard clusters.

At the same time, the yield from v. Privetnoe (cluster IV), distinguished from other clusters by high WI, HTC values and the least amount of precipitation during the growing season, was characterized by the highest sugar content, $\mathrm{pH}$, GAI and RI indices: on average by $15 \%, 6 \%, 32 \%$ and $31 \%$ above corresponding average values in Crimea. It is known that the temperature factor affects the intensity of photosynthesis, migration of nutrients in the plant, accumulation of sugars, and reduction of organic acids during grape ripening [26, 27]. The lowest value (7-10\% less than the average values in Crimea) of sugars content was noted in the yield from the vineyards of cluster I, and the active acidity - from the vineyards of cluster VI. According to the other indices of carbohydrate-acid complex, the yield from the vineyards of clusters I and VI had comparable values. In general, the content of sugars, $\mathrm{pH}$, GAI, and RI correlate inversely $(\mathrm{r}=(-0.47)-(-0.64)$ at $\alpha<0.05)$ with the amount of precipitation during the growing season; directly with HTC $(\mathrm{r}=0.41-0.46)$.

The analysis of the data on the phenolic complex of 'Cabernet Sauvignon' grapes showed that the intracluster dispersion of the technological reserve of phenolic substances, due to the year of harvest [28], exceeded that between vineyard clusters (Table 2). The same can be said about the indices reflecting the degree of transition of phenolic substances from the solid parts of berries into wort, both by pressing of berries and during the 4-hour infusion of the mash. Nevertheless, the values of $\mathrm{Ph}_{0} / \mathrm{TRPh}$ and $\mathrm{Ph}_{4} / \mathrm{TRPh}$ differed significantly (U-test $=216$ and 180 at $\alpha<0.01$ ) from vines from cluster II, with values 1.3 and 1.5 times lower than in grapes from other vineyard clusters. On the contrary, the degree of transfer of phenolic substances into must during infusion of mash in the yield from vineyards I and III of clusters was 1.5 times higher (U-test $=238$ at $\alpha<0.02$ ) than the same in the yield from other vineyards. The results of the research are consistent with the previously obtained data [28], reflecting the high level of transition of phenolic substances into must during processing of 'Cabernet Sauvignon' grapes from the Mountain valley and Mountain-valley seaside regions of the South Coast of Crimea. The $\mathrm{Ph}_{0} / \mathrm{TRPh}$ and $\mathrm{Ph}_{4} / \mathrm{TRPh}$ values are due, on the one hand, to the permeability of secondary cell walls of the skin; on the other hand, to the oxidative transformation of phenolic substances and their sedimentation [29, 30]. It was noted that only the harvest from the vineyards of v.v. Privetnoe (cluster IV), Plodovoe and Osipenko (cluster V) differed significantly from grapes from other sites in monophenolmonooxygenase activity, which was 1.6 times lower (U-test $=70.5$ at $\alpha<0.006)$. A direct correlation $(\mathrm{r}=0.35-0.51)$ of monophenolmonooxygenase activity as well as its relation to phenolic components being the main substrate $\left(\mathrm{A}_{\mathrm{MPhMO}} / \mathrm{Ph}_{0}\right)$ with the sum of active temperatures above $10{ }^{\circ} \mathrm{C}$, Huglin index, precipitation per year and per growing season was revealed.

A significant $(\alpha<0.02)$ dispersion of the potential amount of anthocyanins $\left(\mathrm{ApH}_{1.0}\right)$ and their easily extractable fractions $\left(\mathrm{ApH}_{3.2}\right)$ in the yield obtained from the vineyards of different fractions; and at $\alpha<0.05$ the proportion of easily extractable fractions in the anthocyanin complex was revealed. The lowest (U-test $=167-180$ at $\alpha<0.01$ ) accumulation of anthocyans, including easily extractable, was characteristic of the yield obtained from the coastal vineyards near Yalta and Livadia settlement (II cluster) and from the vineyards of v. Plodovoe and v. Osipenko (V cluster): the values of parameters $\mathrm{ApH}_{1.0}$ and $\mathrm{ApH}_{3.2}$ in the grapes from these plots were 1.4 and 1.5 times lower than in the other vineyards of Crimea. At the same time, the highest value of extractability of anthocyans (Ea) was noted in grapes from the village Privetnoe (cluster IV) $-56 \pm 10 \%$. As shown by our studies [19], the anthocyanin complex of the 2017-2020 yield from the village of Privetnoe was characterized by a high proportion ( $77 \%$ on average) of malvidin-3-O- $\beta$-D-glucoside and its derivatives, which indicates grape maturity, and directly correlates with the Winkler index and the average temperature of the growing season of the vineyard area. In the 
present studies it was shown that anthocyanin extractability directly correlated with such indicators of area heat availability as the Huglin $(r=0.39)$ and Winkler $(r=0.32)$ indices.

Table 2. Values* of physico-chemical and biochemical parameters of the yield obtained in the vineyards of different clusters.

\begin{tabular}{|c|c|c|c|c|c|c|c|c|}
\hline \multirow[b]{2}{*}{ Parameters } & \multicolumn{6}{|c|}{ Vineyard clusters } & \multirow[b]{2}{*}{$\begin{array}{l}\text { All of the } \\
\text { vineyards }\end{array}$} & \multirow{2}{*}{\begin{tabular}{|c} 
Significance \\
level (F- \\
criterion) of \\
dispersion of \\
the index \\
between \\
vineyards, \\
$\alpha$, less than
\end{tabular}} \\
\hline & I & II & III & IV & V & VI & & \\
\hline $\begin{array}{l}\text { Sugar } \\
\text { content, } \\
\text { g. L }{ }^{-1}\end{array}$ & $200 \pm 8$ & $222 \pm 29$ & $239 \pm 13$ & $256 \pm 22$ & $212 \pm 7$ & $221 \pm 15$ & $222 \pm 27$ & 0.0002 \\
\hline $\begin{array}{l}\text { Titrated } \\
\text { acids, g. L }{ }^{-1}\end{array}$ & 7. $2 \pm 1.2$ & $7.1 \pm 1.1$ & $5.7 \pm 1.3$ & $6.1 \pm 1.6$ & $6.6 \pm 1.0$ & $7.7 \pm 0.4$ & $6.8 \pm 1.3$ & 0.13 \\
\hline $\mathrm{pH}$ & $3.29 \pm 0.05$ & $53.41 \pm 0.15$ & $3.40 \pm 0.18$ & $3.60 \pm 0.25$ & $3.27 \pm 0.16$ & $3.16 \pm 0.23$ & $3.38 \pm 0.19$ & 0.004 \\
\hline GAI & $2.9 \pm 0.5$ & $3.2 \pm 0.8$ & $4.4 \pm 1.0$ & $4.5 \pm 1.6$ & $3.3 \pm 0.5$ & $2.9 \pm 0.5$ & $3.5 \pm 1.1$ & 0.008 \\
\hline RI & $215 \pm 9$ & $261 \pm 52$ & $277 \pm 35$ & $336 \pm 71$ & $228 \pm 29$ & $220 \pm 17$ & $257 \pm 58$ & 0.0003 \\
\hline $\begin{array}{l}\text { TRPh, } \\
\text { mg. L }^{-1}\end{array}$ & $1814 \pm 431$ & $1 \mid 2217 \pm 716$ & $2229 \pm 428$ & $2298 \pm 468$ & $1903 \pm 606$ & $1986 \pm 713$ & $2087 \pm 572$ & 0.5 \\
\hline $\begin{array}{l}\mathrm{Ph}_{0} / \mathrm{TRPh}, \\
\%\end{array}$ & $21 \pm 12$ & $16 \pm 4$ & $24 \pm 17$ & $24 \pm 4$ & $19 \pm 11$ & $23 \pm 1$ & $20 \pm 10$ & 0.6 \\
\hline $\begin{array}{l}\mathrm{Ph}_{4} / \mathrm{TRPh}, \\
\%\end{array}$ & $28 \pm 16$ & $20 \pm 4$ & $30 \pm 23$ & $24 \pm 4$ & $23 \pm 10$ & $25 \pm 0.8$ & $25 \pm 12$ & 0.7 \\
\hline $\begin{array}{l}\mathrm{ApH} \mathrm{H}_{1.0}, \\
\mathrm{mg} . \mathrm{L}^{-1}\end{array}$ & $914 \pm 484$ & $609 \pm 326$ & $1211 \pm 256$ & $1044 \pm 274$ & $633 \pm 128$ & $1182 \pm 319$ & $857 \pm 401$ & 0.02 \\
\hline $\begin{array}{l}\mathrm{ApH} \mathrm{H}_{3.2}, \\
\mathrm{mg} . \mathrm{L}^{-1}\end{array}$ & $394 \pm 199$ & $265 \pm 99$ & $444 \pm 136$ & $564 \pm 98$ & $296 \pm 48$ & $602 \pm 271$ & $385 \pm 175$ & 0.002 \\
\hline $\mathrm{Ea}, \%$ & $43 \pm 7$ & $47 \pm 14$ & $36 \pm 6$ & $56 \pm 10$ & $47 \pm 5$ & $50 \pm 9$ & $46 \pm 11$ & 0.05 \\
\hline $\begin{array}{l}\text { AMPhMO } \\
10^{2}, \text { items }^{-}\end{array}$ & $8.9 \pm 2.4$ & $10.7 \pm 2.6$ & $12.0 \pm 5.4$ & $7.1 \pm 2.6$ & $6.9 \pm 0.9$ & $10.7 \pm 7.9$ & $9.3 \pm 3.5$ & 0.06 \\
\hline
\end{tabular}

$*$ means \pm SD

The selected vineyard clusters, based on the aggregate content of the main and secondary $\left(\mathrm{ApH}_{1.0} ; \mathrm{ApH}_{3.2}, \mathrm{~A}_{\mathrm{MPhMO}}\right)$ grape metabolites and technological indicators (GAI, RI, Ea), are discriminated against Wilks L. $=0.09$ at $\alpha<0.00001$, which is illustrated on Figure 3. 


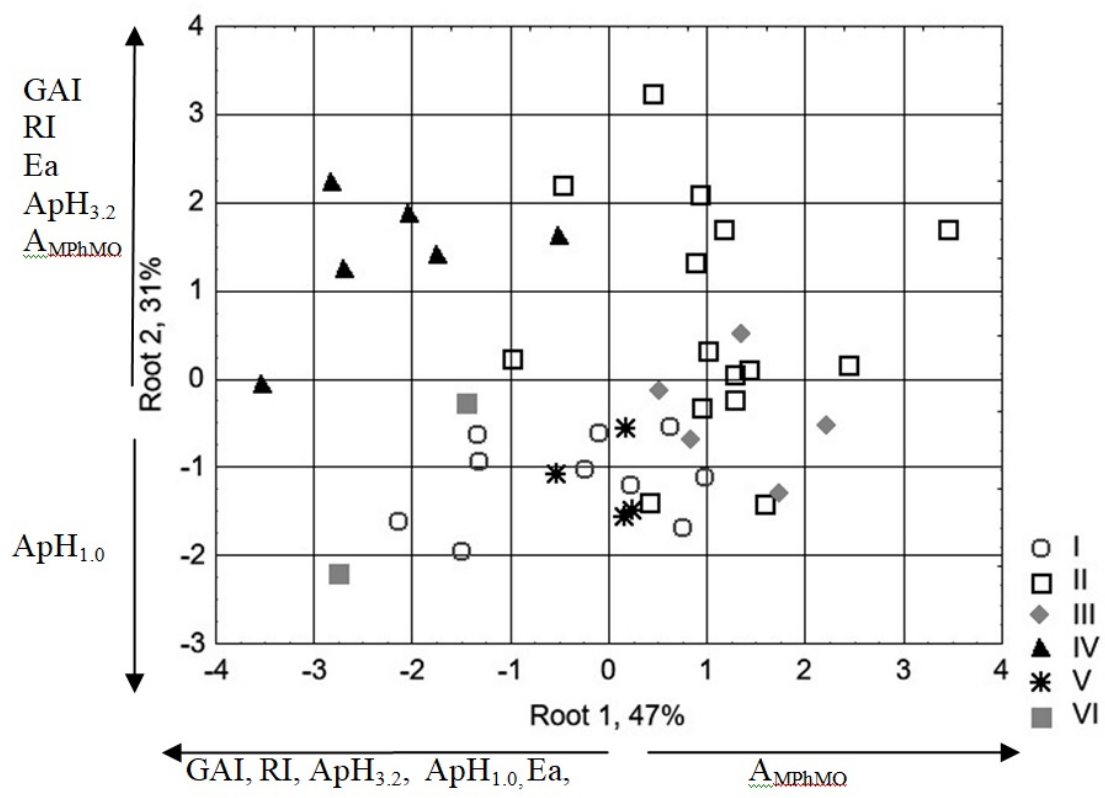

Fig. 3. Diagram showing the differences between the identified clusters of vineyards in terms of the parameters of phenolic and carbohydrate-acid complexes: Cluster I - Alushta + Veseloye + Morskoye + Orlovka; cluster II - Yalta + Livadia (2); cluster III - Livadia (1) + Lazurnoye + Sunny Valley; cluster IV - Privetnoye; cluster V - Plodovoye + Osipenko; cluster VI - Vilino + Uglovoye.

\section{Conclusion}

Study of regularities of agro-ecological factors influence on formation of qualitative characteristics of yield and wine is an integral condition of selection of territories for vineyard. The present work is aimed at research of similarity and differences of agroclimatic conditions of 14 industrial vineyards of cv. 'Cabernet Sauvignon' located on the territory of the Crimean peninsula and parameters of carbohydrate-acid and phenolic maturity of the harvest. Determination of agroclimatic parameters of vineyards was carried out using the method of geoinformation modeling, digital terrain model SRTM-3, global climatic model Worldclim ver. 2.0 and mathematical models developed by us. We have identified 6 clusters of vineyards which significantly differ from each other in terms of heat and moisture availability (Wilks L. $=0.0006 ; \alpha<0.00001$ ), as well as dispersion of primary and secondary metabolites, reflecting peculiarities of carbohydrate-acid and phenolic complex of the crop (Wilks L. $=0.09$ at $\alpha<0.00001$ ). Correlations of sugar content, active acidity index, anthocyanins extractability, monophenolmonooxygenase activity, glucoacidometric index and grape ripeness index with Huglin and Winkler indices, sum of active temperatures above $10^{\circ} \mathrm{C}$, sum of precipitation per year and vegetation period were revealed.

Studies will continue to develop mathematical models adequately reflecting the dependence of climatic parameters and quality indicators of grapes and wine.

\section{Conflict of interest}

The authors declare that there is no conflict of interest. 


\section{Acknowledgements}

The authors are grateful to junior researchers O. Zaitseva, N. Lutkova, for performing physical and chemical analyses and participating in the preparation of the publication.

\section{Financial source}

The reported study was funded by RFBR, project number 20-016-00075.

\section{References}

1. J. Drappier, C. Thibon, A. Rabot, L. Geny-Denis, Critical Reviews in Food Science and Nutrition, 59(8), 1-17 (2017) DOI: 10.1080/10408398.2017.1355776

2. C. Van Leeuwen. and Ph. Darriet, Journal of Wine Economics, 11(1), 150-167 (2016) DOI: $10.1017 /$ jwe.2015.21

3. C. Jarvis, E. Barlow, R. Darbyshire, R. Eckard, I., Goodwin International Journal of Biometeorology, 61, 1849-1862 (2017) DOI: 10.1007/s00484-017-1370-9

4. E. V. Ostroukhova, I. V. Peskova, E. A. Rybalko, L. B. Tvardovskaya, Magarach. Viticulture and Winemaking, 2, 28-31 (2015) (in Russian)

5. E. A. Rybalko, E. V. Ostroukhova, N. V. Baranova, I. V. Peskova, V. Y. Borisova, Horticulture and Viticulture of the South Russia, 66(6), 149-167 (2020) (in Russian) DOI: $10.30679 / 2219-5335-2020-6-66-149-167$

6. E. A. Egorov, V. S. Petrov, Vestnik of the Russian agricultural science, 5, 51-54 (2017) (in Russian)

7. M. Kryza, M. Szymanowski, M. Błaś, K. Migała, M. Werner, M. Sobik, Theoretical and Applied Climatology, 122, 207-218 (2015) DOI: 10.1007/s00704-014-1296-7

8. V. Comte, V. Zufferey, J. Rösti, P. Calanca, M. Rebetez, Adaptation strategies of a cold climate vineyard to climate change, the case of the Neuchatel region in Switzerland, in Proceedings of the 42nd Congress of Vine and Wine 17th General Assembly of the OIV, Switzerland, 45-47 (2019)

9. E. Rybalko, N. Baranova, E. Loupian, V. Tolpin, A. Kashnitskiy, I. Uvarov, Yu. Krasheninnikova, V. Ivanchenko, Current problems of remote sensing of the Earth from space, 13(1), 79-92 (2016) (in Russian) DOI: 10.21046/2070-7401-2016-13-1-7992

10. V. Tolpin, E. Rybalko, N. Baranova, A. Kashnitskiy, E. Loupian, I. Uvarov, Current problems of remote sensing of the Earth from space, 14(1), 101-110 (2017) (in Russian) DOI: 10.21046/2070-7401-2017-14-1-101-110

11. L. Irimia, C. V. Patriche, H. Quenol, Cercetări Agronomice în Moldova, 2(150), 75-84 (2012) DOI: 10.2478/v10298-012-0017-6

12. S. R. Schultze, P. Sabbatini, J. A. Andresen, Am. Journal of Enology and Viticulture, 65(2), 179-188 (2014) DOI: 10.5344/ajev.2013.13063

13. N. K. Jones, Journal of Wine Research, 29(2), 120-129 (2018) DOI: 10.1080/09571264.2018.1472074

14. C. van Leeuwen, B. Bois, E3S Web of Conferences, 50, 01044 (2018) DOI: $10.1051 / \mathrm{e} 3$ sconf $/ 20185001044$ 
15. F. Lecourieux, C. Kappel, P. Pieri, J. Charon, J. Pillet, G. Hilbert, C. Renaud, E. Gomes, S. Delrot, D. Lecourieux, Front. Plant Sci, 8, 53 (2017) DOI: 10.3389/fpls.2017.00053

16. N. Movahed, C. Pastore, A. Cellini, G. Allegro, G. Valentini, S. Zenoni, E. Cavallini, E. D’Incà, G.B. Tornielli, I. Filippetti, J. Plant Res, 129, 513-526 (2016) DOI: 10.1007/s10265-016-0786-3

17. C. Pastore, S. Dal Santo, S. Zenoni, N. Movahed, G. Allegro, G. Valentini, I. Filippetti, G.B. Tornielli, Front. Plant Sci., 8, 929 (2017) DOI: 10.3389/fpls.2017.00929

18. M. J. García-Esparza, I. Abrisqueta, I. Escriche, D. S. Intrigliolo, I. Álvarez, V. Lizama, Vitis, 57, 83-91 (2018) DOI: 10.5073/vitis.2018.57.83-91

19. E. V. Ostroukhova, E. A. Rybalko, S. V. Levchenko, V. A. Boiko, D. Yu. Belash, M. Viugina, E3S Web of Conferences, 247, 01013 (2021) DOI: 10.1051/e3sconf/202124701013

20. E. A. Rybalko, Magarach. Viticulture and Winemaking, 2, 10-11 (2014) (in Russian)

21. E. A. Rybalko, N. V. Baranova, Environmental control systems, 6(26), 101-105 (2016) (in Russian)

22. E. A. Rybalko, N. V. Baranova, V. Y. Borisova, Winemaking and Viticulture, 1, 18-23 (2020) (in Russian)

23. E. A. Rybalko, N. V. Baranova, V. Y. Borisova, Magarach. Viticulture and Winemaking, 22(2), 120-124 (2020) (in Russian) DOI: 10.35547/IM.2020.29.71.007

24. Compendium of international methods of wine and must analysis. Paris (2017)

25. Y. Glories, N. Vivas, Maturation phenolique: definition et controle, in resume d'intervention presente par Julien Ducruet, Universite Bordeaux II, 1-10 (1998) (In France)

26. R. Ferrer-Gallego, J. M. Hernandez-Hierro, J. C. Rivas-Gonzalo, M. T. EscribanoBailon, Analytica Chimica Acta, 732, 73-77 (2012) DOI: 10.1016/j.aca.2011.12.072

27. E. V. Ostroukhova, I. V. Peskova, P. A. Probeygolova, N. Y. Lutkova, O. V. Zaitseva, S.A. Yeremenko, Magarach. Viticulture and Winemaking, 20(3), 77-79 (2018) (in Russian)

28. E. V. Ostroukhova, I. V. Peskova, P. A. Probeygolova, N. Y. Lutkova, Development Problems of Regional Agro-industrial Complex, 3(35), 184-193 (2018) (in Russian)

29. P. del Rio, J. Kennedy, J. A. Kenne, Am. J. Enol. Vitic., 57, 125-132 (2006)

30. E. V. Ostroukhova, Magarach. Viticulture and Winemaking, 2, 16-18 (2011) (in Russian) 